\title{
Rethinking London's economy and economic future
}

\author{
Myfanwy Taylor
}

If thinking about what London's economy might be like in 2062 seems fanciful, what about 2031 ? For this is the timeframe over which the present Mayor of London's Spatial Development Strategy (the 'London Plan') seeks to influence the city's development. Ideas about what will happen to London's economy in the future are thus already shaping Mayoral policies and priorities.

\section{Planning for growth}

The vision of London's future in the London Plan (Mayor of London, 2011) is one of continued growth. It projects a future London of 8.82 million people (up 15.7 per cent from 2006) and 4.68 million jobs (up 16.5 per cent from 2007). Much of what follows is then aimed at providing the infrastructure and spaces to accommodate this projected growth: 'the only prudent course is to plan for continued growth' (p.23)

The targeting of growth is, in fact, open to challenge on many grounds, as was argued by Friends of the Earth (2010), Michael Edwards (n.d) and David Fell (n.d), amongst others, in their submissions to the examination of the draft London Plan. Here I focus on one specific challenge, namely that the growth that is imagined risks increasing inequality and worsening the present crisis of reproduction in London. This trend can be seen in development schemes, for example at Wards Corner, Tottenham (Wards Corner Community Coalition, n.d), that do not recognise and value but instead would displace and destroy existing economic activities which support livelihoods and deliver goods and services to London's diverse populations.

Interestingly, the London Plan (Mayor of London, 2011) includes no projections of the city's future inequalities. The solution to the problem is seen to lie in 'geographically targeted approaches to development and regeneration, focusing investment and action on places with the highest need' (p.25). Connections between the nature of economic growth and deprivation are not acknowledged, neither is the now overwhelming evidence that targeted regeneration displaces the poor and the businesses and organisations that serve them (Porter \& Shaw, 2009).

\footnotetext{
How to cite this book chapter:

Taylor, M. 2013. Rethinking London's economy and economic future. In: Bell, S and Paskins, J. (eds.) Imagining the Future City: London 2062. Pp. 131-135. London: Ubiquity Press. DOI: http://dx.doi. org/10.5334/bag.s
} 


\section{Growing the 'global' city}

Part of the problem with the Greater London Authority's (GLA's) projected future economy of London is the nature of the growth imagined. $38 \%$ of the 776,000 new jobs anticipated by 2031 will come, the Plan projects, from business and financial services (Mayor of London, 2011). It is these sectors, then, whose interests the London Plan's policies primarily seek to serve. This form of representing the city and its economy as 'global' and 'world-class' makes the diversity of London's economy invisible, despite its importance to the city's long-term success and resilience (Buck et al, 2002). In other words, presenting London as a global city is a form of synecdoche, in which the part (financial and business services) is made to stand for the whole (London's diverse economy) (Amin \& Graham, 1997). This matters because the presentation of London's success as resting fundamentally on the continued retention and attraction of international firms and workers in these sectors risks framing all other activities as secondary and unproductive of future growth. This reduces the space to put forward alternative approaches to urban economic development and planning that might offer greater possibilities for aligning social and economic development in London.

\section{Re-thinking London's economy and economic future}

We urgently need to develop multiple alternative ways of thinking about London's economy and its economic future. The Greater London Authority's vision is irreconcilable both with the need to reduce carbon emissions and with a desire for a more just and equitable society. Furthermore, the choices London makes about what kind of economy it wants will have repercussions for people and places elsewhere, as indeed they have in the past. Where might we look for inspiration in developing alternative ideas for London's economy in 2031 or even 2062 ?

\section{The diverse economy}

If we are to think imaginatively about London's economy today, we must first recognise that the idea of economy as being somehow separate from society - being subject instead to the self-regulating rationalities of an abstract market - is itself a construction of our own making (Mitchell, 2002). In this, J.K. Gibson-Graham's work is useful in showing that capitalism is but one way in which economic systems can be and have been organised by society (Gibson-Graham, 1996). Drawing on feminist and queer perspectives, she works to open up the notion of the diverse economy, 'representing and documenting the huge variety of economic transactions, labor practices and economic organizations that contribute to social well-being' (Gibson-Graham, 2008: p.615).

The diverse economy encompasses unpaid labour in the home or caring for others, informal exchange amongst friends, neighbours and members of alternative trading schemes, volunteering activities, as well as all kinds of ethical, green or otherwise-oriented market activities. As feminist geographers amongst others have shown, these activities are intimately connected with paid work and play an important role in keeping cities working. Seeing London's economy through this lens might open up a wider range of policies to support its diversity, such as stronger protection and support for trading and enterprise spaces for markets, community groups and small businesses, as well as provision of employment space close to residential space. 


\section{Thinking about London from the global South}

Postcolonial urban studies make a direct challenge to Western notions of modernity and development, suggesting that their relevance to cities outside their geographical origins is limited and, further, that that Western cities themselves might benefit from paying greater attention to theory and practice emerging from elsewhere (Robinson, 2002; 2006). For London, whose present global connections and influences rest on and remind us of its imperial and colonial past (Massey, 2007), postcolonial theory makes a particularly pertinent challenge.

Poorer cities may have much to teach London, amongst other cities, specifically in relation to the entwining of the social and the economic in cities. As Jenny Robinson argues (Robinson, 2006), because basic needs and developmental agendas are much more powerfully present in the global South, they more powerfully assert themselves into strategic debates regarding urban growth. This means 'local governments and development organisations are eager to find effective ways of expanding local economic opportunities through supporting the livelihood strategies of the poorest city dwellers or, at the very least, not disrupting existing activities' (p.153). Such a perspective would pay more attention to the skills and capabilities that the urban poor deploy in order to 'make do' in cities, as AbdouMaliq Simone (2001) has explored in relation to urban Africa, for example. Thinking about London from these departure points might prompt us to give greater emphasis to issues of urban reproduction and survival, recognising and valuing the spaces in which diverse economic activities are already underway and might be nurtured further.

\section{Already-existing alternative economies}

Finally, we can take inspiration from the communities and organisations who are already working to protect and support diverse economies in London. In Brixton, an alternative currency has been launched to encourage money to 'stick' to Brixton and support local independent trade and business (The Brixton Pound, n.d). In Tottenham, the Wards Corner Community Coalition continues to fight against plans to demolish and re-develop Wards Corner, currently an important site for market traders, especially in speciality Latin American goods and services, and to develop an alternative Community Plan (Wards Corner Community Coalition, n.d) across London, we can look to the example of Just Space, an 'informal alliance of community groups, campaigns and concerned independent organisations that came together to challenge policies in the London Plan and take part in the "Examination in Public" in 2006 (Just Space, n.d), which continues to play an important role in challenging the growth assumptions of the London Plan and in developing alternative perspectives on London's economy. Just Space's activities have been supported in various was by university-based researchers and students, many of them at University College London. Further sustained engagement between community groups and university-based researchers and students, amongst others, including through UCL's London 2062 initiative, offers great potential in the development and proliferation of diverse new ways of thinking about London's economy and economic future.

\section{Acknowledgements}

In writing this paper, I have benefited from participating and tutoring in a course on 'Community Participation in City Strategies' as part of the MSc in Urban Studies at UCL, and from my involvement with the Brixton Pound, Wards Corner Community Coalition and Just Space. Thanks also to my supervisors, Jenny Robinson and Michael Edwards, and to the ESRC for supporting my PhD studies at UCL. 


\section{References}

Amin A. and Graham S. 1997. The Ordinary City. Transactions of the Institute of British Geographers. 22(4): 411-429

Buck N., Gordon I., Hall P., Harloe M. and Kleinman M. (eds.). 2002. Working Capital: Life and Labour in Contemporary London. London: Routledge

Edwards M. n.d. Draft Replacement London Plan / Economic Development Strategy: Comment and objection from Michael Edwards. Available from http://justspace2010.wordpress.com/ welcome-to-just-space/submissions-about-the-plan/edwards-economy/. [Accessed 23 April 2012]

Fell D. n.d. David Fell - Economy. Available from http://justspace2010.wordpress.com/welcometo-just-space/submissions-about-the-plan/david-fell-economy/. [Accessed 23 April 2012]

Friends of the Earth. 2010 (January). Friends of the earth (foe). Available from: http://justspace2010.wordpress.com/welcome-to-just-space/submissions-about-the-plan/friends-ofthe-earth-foe/. [Accessed 23 April 2012]

Gibson-Graham JK. 1996. The End of Capitalism (As We Knew It): A Feminist Critique of Political Economy. Minneapolis: University of Minnesota Press

Gibson-Graham JK.2008. Diverse economies: performative practices for 'other worlds'. Progress in Human Geography. 32(5):613-632

Just Space. n.d About Just Space. Available online at http://justspace2010.wordpress.com/welcome-to-just-space/about-2/ [Accessed 23 April 2012]

Massey D. 2007. World City. Cambridge: Polity Press

Mayor of London. 2011. The London Plan: Spatial Development Strategy for Greater London - July 2011. London: GLA

Mitchell T. 2002. Rule of experts: Egypt, techno-politics, modernity. London: University of California Press

Porter L. and Shaw K. (eds). 2009. Whose Urban Rennaissance? An international comparison of urban regeneration strategies. London: Routledge

Robinson J. 2002. Global and World Cities: A View from Off the Map. International Journal of Urban and Regional Research. 26(3):531-554

Robinson J. 2006. Ordinary cities: between modernity and development. London: Routledge

Simone A. 2001. Straddling the Divides: Remaking Associational Life in the Informal African City. International Journal of Urban and Regional Research. 25(1):102-117.

The Brixton Pound. n.d. Key Facts. Available at http://brixtonpound.org/about/keyfacts/. [Accessed 23 April 2012]

Wards Corner Community Coalition. History. n.d. Available from http://wardscorner.wikispaces. com/History. [Accessed 23 April 2012] 


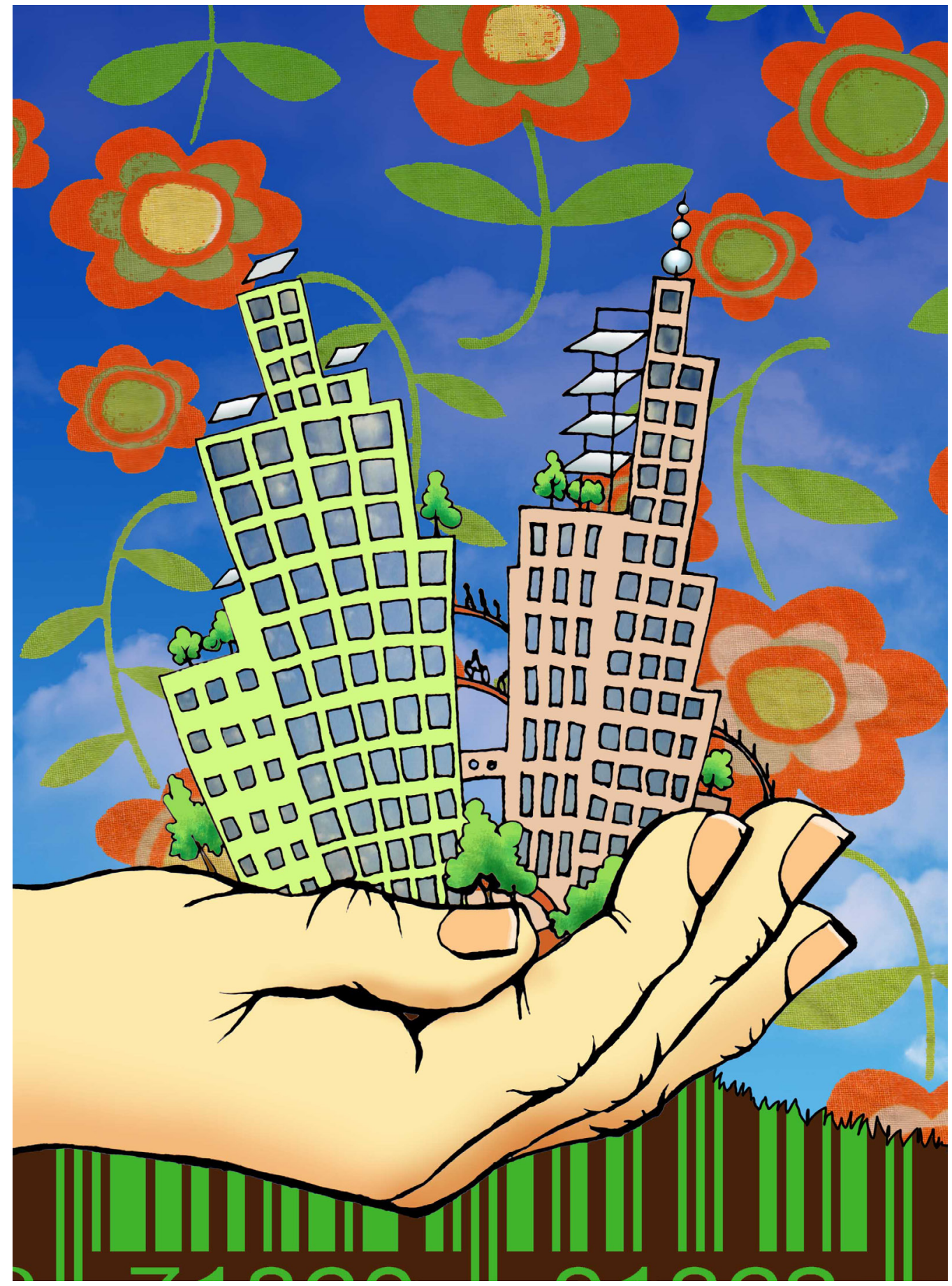

